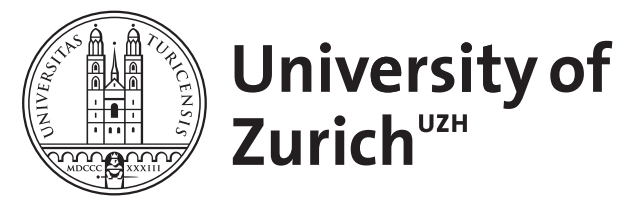

Zurich Open Repository and Archive

University of Zurich

University Library

Strickhofstrasse 39

CH-8057 Zurich

www.zora.uzh.ch

Year: 2015

Evaluation of eating and rumination behaviour using a noseband pressure sensor in cows after right-flank laparotomy for correction of left displaced abomasum

Braun, Ueli ; Trösch, L ; Nuss, Karl

DOI: https://doi.org/10.17236/sat00025

Posted at the Zurich Open Repository and Archive, University of Zurich

ZORA URL: https://doi.org/10.5167/uzh-112442

Journal Article

Published Version

Originally published at:

Braun, Ueli; Trösch, L; Nuss, Karl (2015). Evaluation of eating and rumination behaviour using a noseband pressure sensor in cows after right-flank laparotomy for correction of left displaced abomasum. Schweizer Archiv für Tierheilkunde, 157(6):345-347.

DOI: https://doi.org/10.17236/sat00025 


\title{
Evaluation of eating and rumination behaviour using a noseband pressure sensor in cows after right-flank laparotomy for correction of left displaced abomasum
}

\author{
U. Braun, L. Trösch, K. Nuss \\ Department of Farm Animals, Vetsuisse Faculty, University of Zurich
}

\section{Introduction}

The goal of this study was to investigate eating and rumination behaviour in cows during the first five days after surgical correction of left displaced abomasum (LDA). In addition, it should be examined if the values obtained differed from those obtained from healthy control cows.

\section{Animals, Material and Methods}

As controls, ten cows, $4.1 \pm 1.65$ years old, were used. They were $170 \pm 53.6$ days in milk, and daily milk yield amounted $28.2 \pm 4.8 \mathrm{~kg}$. Ten cows with left displaced abomasum, $5.0 \pm 1.05$ years old, underwent right-flank omentopexy for correction of LDA. They were from 5 to 77 days (median, 14 days) in milk, and daily milk yield before the occurrence of LDA amounted $30.5 \pm 6.47 \mathrm{~kg}$. All cows underwent clinical examination to confirm that they were healthy (controls) or had LDA. The operation and postoperative treatment of cows with LDA was performed as described earlier (Braun et al., 2011). The cows had free access to hay and water. In addition they received $2 \mathrm{~kg}$ corn pellets and $2 \mathrm{~kg}$ protein concentrate. The recording of eating and rumination was performed using pressure sensor technique as described (Braun et al., 2013) for five days immediately after surgery. For each cow, the following variables were determined from the uploaded data: Total daily eating and rumination times; number of regurgitated cuds per day; number of chewing cycles per cud. The statistical analysis included the calculation of means and standard deviations and the performance of the Wilk Shapiro-test for normality. Differences within groups were analysed using the Bonferroni test. A value of $\mathrm{P}<0.05$ was considered significant.

\section{Results}

The results of the initial clinical examination were described in detail (Trösch, 2013). The control cows were healthy and had a normal appetite throughout the study period. In LDA cows, general condition and demeanour were affected and appetite and milk yield were reduced. Activities of liver enzymes were elevated. Seven cows had elevated urinary acetoacetate concentrations. All LDA cows had abomasal reflux syndrome. The general condition and demeanour of the operated cows normalised within two to three days and the cows were discharged from the clinic after another two or three days following the three-day postoperative therapy.

The mean total daily eating time did not change during the five-day study period and did not differ between the two groups (Tab. 1). It varied from 425 to 469 minutes in the controls and from 384 to 409 minutes in the LDA cows. The mean total daily rumination time varied from 441 to 479 minutes in the controls. In LDA cows, it increased significantly and from 378 minutes on day 1 to 501 minutes on day $5(\mathrm{P}<0.05)$. The mean daily number of chewed cuds did not differ within and between groups, whereas the mean number of chewing cycles per cud differed significantly. It ranged from 58 to 60 in controls and from 43 to $54(\mathrm{P}<0.01)$ in LDA cows. In the latter, the number of chewing cycles per cud increased significantly over the five-day study period $(\mathrm{P}<0.05)$.

\section{Discussion}

The mean total daily eating time varied from 425 to 469 minutes (7.1 to 7.8 hours), compared with 4 hours (Freer et al., 1962), 4.2 hours (Freer and Campling,
DOI $10.17236 /$ sat00025

Received: 27.05 .2014 Accepted: 20.08.2014 
Table 1: Eating and rumination behaviour during five days in ten healthy control cows and in ten cows after omentopexy for surgical correction of LDA (mean $\pm \mathrm{sd}$, range in parentheses).

\begin{tabular}{|c|c|c|c|c|c|c|}
\hline \multirow[b]{2}{*}{ Variable } & \multirow[b]{2}{*}{ Group } & \multicolumn{5}{|l|}{ Day } \\
\hline & & 1 & 2 & 3 & 4 & 5 \\
\hline \multirow[t]{2}{*}{ Total daily eating time (min.) } & Controls & $\begin{array}{l}441 \pm 65 \\
(363-580)\end{array}$ & $\begin{array}{l}433 \pm 70 \\
(332-523)\end{array}$ & $\begin{array}{l}469 \pm 72 \\
(326-540)\end{array}$ & $\begin{array}{l}456 \pm 58 \\
(368-551)\end{array}$ & $\begin{array}{l}425 \pm 43 \\
(392-530)\end{array}$ \\
\hline & LDA & $\begin{array}{l}384 \pm 112 \\
(259-598)\end{array}$ & $\begin{array}{l}477 \pm 61 \\
(392-598)\end{array}$ & $\begin{array}{l}438 \pm 72 \\
(364-510)\end{array}$ & $\begin{array}{l}439 \pm 70 \\
(304-536)\end{array}$ & $\begin{array}{l}409 \pm 96 \\
(251-566)\end{array}$ \\
\hline \multirow[t]{2}{*}{ Total daily rumination time (min.) } & Controls & $\begin{array}{l}441 \pm 69 \\
(331-524) \\
\end{array}$ & $\begin{array}{l}461 \pm 49 \\
(381-546)\end{array}$ & $\begin{array}{l}475 \pm 34 \\
(431-527)\end{array}$ & $\begin{array}{l}479 \pm 42 \\
(429-535)\end{array}$ & $\begin{array}{l}479 \pm 55 \\
(368-542)\end{array}$ \\
\hline & LDA & $\begin{array}{l}378 \pm 118 \\
(191-542)\end{array}$ & $\begin{array}{l}496 \pm 77^{*} \\
(398-603)\end{array}$ & $\begin{array}{l}488 \pm 89 \\
(345-654)\end{array}$ & $\begin{array}{l}482 \pm 82 \\
(356-598)\end{array}$ & $\begin{array}{l}501 \pm 71^{*} \\
(403-616)\end{array}$ \\
\hline \multirow[t]{2}{*}{ Number of cuds per day } & Controls & $\begin{array}{l}475 \pm 112 \\
(307-663)\end{array}$ & $\begin{array}{l}509 \pm 86 \\
(374-666)\end{array}$ & $\begin{array}{l}486 \pm 102 \\
(343-667)\end{array}$ & $\begin{array}{l}533 \pm 83 \\
(419-681)\end{array}$ & $\begin{array}{l}532 \pm 77 \\
(401-633)\end{array}$ \\
\hline & LDA & $\begin{array}{l}465 \pm 122 \\
(255-625)\end{array}$ & $\begin{array}{l}574 \pm 72 \\
(457-675)\end{array}$ & $\begin{array}{l}521 \pm 73 \\
(416-634)\end{array}$ & $\begin{array}{l}536 \pm 67 \\
(421-658)\end{array}$ & $\begin{array}{l}550 \pm 85 \\
(440-679)\end{array}$ \\
\hline \multirow[t]{2}{*}{ Chewing cycles per cud } & Controls & $\begin{array}{l}58 \pm 4 \\
(52-65)\end{array}$ & $\begin{array}{l}60 \pm 5 \\
(50-68)\end{array}$ & $\begin{array}{l}60 \pm 4 \\
(56-67)\end{array}$ & $\begin{array}{l}60 \pm 4 \\
(52-64)\end{array}$ & $\begin{array}{l}59 \pm 5 \\
(52-66)\end{array}$ \\
\hline & LDA & $\begin{array}{l}43 \pm 6 \\
(34-57)\end{array}$ & $\begin{array}{l}47 \pm 8 \\
(36-64)\end{array}$ & $\begin{array}{l}50 \pm 6 \\
(40-59)\end{array}$ & $\begin{array}{l}52 \pm 5^{*} \\
(46-64)\end{array}$ & $\begin{array}{l}54 \pm 6^{*} \\
(47-65)\end{array}$ \\
\hline
\end{tabular}

1965), 5.5 hours (Welch and Hooper, 1988; Senn et al., 1995), 4 to 7 hours (Beauchemin, 1991), 4 to 9 hours (Gürtler, 1974) and 4 to 12 hours (Dulphy et al., 1980). A possible reason for the shorter eating times in the 1960s (Freer et al., 1962; Freer and Campling, 1965) is the much smaller production level at that time, which was associated with smaller caloric requirements. The modern dairy cow is bred for high milk yield, which necessitates increased feed intake and thus longer eating times. The total daily rumination time of 441 to 479 minutes (7.4 to 8 hours) corresponded to the upper range reported in other studies (4 to 9 hours; Gürtler, 1974; Hill, 1976; Dulphy et al., 1980; Beauchemin, 1991). The mean number of cuds per day varied from 475 to 533 compared with 360 to 790 (Gürtler, 1974) and 400 to 480 cuds (Piatkowski et al., 1990). In our study, the mean number of chewing cycles per cud was 58 to 60 compared with 52 (Welch and Hooper, 1988) and 40 to 60 (Gürtler, 1974) reported earlier. The number of chewing cycles per cud depends largely on the fibre content of the ration (Beauchemin, 1991); the cows of the present study were fed hay free choice, which may have contributed to the relatively large number of chewing cycles per cud.

In LDA cows, rumination time increased significantly from 378 minutes on day 1 to 501 minutes on day 5 . Also, the mean number of chewing cycles per cud increased significantly over the course of the observation period from 43 to 54 chewing cycles per cud. Theses increases were a reflection of gradual improvement in health and possibly also due to pain control with flunixin meglumine. By contrast, the daily number of cuds did not differ between the two groups. The main effects of right flank omentopexy and postoperative treatment in cows with LDA on the rumination and eating variables were an increase in the daily rumination time and an increase in the number of chewing cycles per cud and per day.

\section{References}

Beauchemin, K. A.: Ingestion and mastication of feed by dairy cattle. Vet. Clin. North Am. (Food Anim. Pract.) 1991, 7: 439-463.

Braun, U., Gorber, U., Hässig, M., Nuss, K.: Ultrasonography of the abdominal wall before and after laparotomy in cows. Schweiz. Arch. Tierheilk. 2011, 153: 71-77.

Braun, U., Trösch, L., Nydegger, F., Hässig, M.: Evaluation of eating and rumination behaviour in cows using a noseband pressure sensor. BMC Vet. Res. 2013, 9: 164.
Dulphy, J. P., Remond, B., Theriez M.: Ingestive behaviour and related activities in ruminants. In: Digestive Physiology and Metabolism in Ruminants. Eds. Y. Ruckebusch, P. Thivend, MTP Press, Lancaster, 1980, 103-123.

Freer, M., Campling, R. C., Balch, C. C.: Factors affecting the voluntary intake of food by cows. 4 . The behaviour and reticular motility of cows receiving diets of hay, oat straw and oat straw with urea. Br. J. Nutr. 1962, 16: 279-295.

Freer, M., Campling, R. C.: Factors affecting the voluntary intake of food by cows. 7. The behaviour and reticular motility of cows given diets of hay, dried grass, concentrates and ground, pelleted hay. Br. J. Nutr. 1965, 19: 195-207. 
Gürtler, H.: Physiologie der Verdauung und Absorption In: Lehrbuch der Physiologie der Haustiere. Hrsg. E. Kolb. Gustav Fischer Verlag, Jena, 1974, 219-422.

Hill, H.: Die Verdauung. In: Lehrbuch der Veterinär-Physiologie. Hrsg. A. Scheunert, A. Trautmann. Paul Parey Verlag, Berlin,Hamburg, 1976, 93-187.

Piatkowski, B., Gürtler, H., Voigt, J.: Futteraufnahme beim Wiederkäuer. In: Grundzüge der Wiederkäuer-Ernährung Hrsg. B. Piatkowski, H. Gürtler, J. Voigt. Gustav Fischer Verlag, Jena, Leipzig, 1990, 133-153.

Senn, M., Dürst, B., Kaufmann, A., Langhans, W.: Feeding patterns of lactating cows of three different breeds fed hay, corn silage, and grass silage. Physiol. Behav. 1995,

58: 229-236.

Trösch, L.: Untersuchungen über das Fressen und Wiederkauen von Kühen mit Hilfe eines Drucksensors im Halfter. Dissertation, Universität Zürich, 2013.

Welch, J. G., Hooper, A. P.: Ingestion of feed and water. In: The Ruminant Animal: Digestive Physiology and Nutrition. Ed. D. C. Church. Prentice Hall, Englewood Cliffs, New Jersey, 1988, 108-117.

\section{Corresponding author}

Ueli Braun, Departement für Nutztiere

Winterthurerstrasse 260

$\mathrm{CH}-8057$ Zürich

Fax: +41 (0)446358904

E-Mail: ubraun@vetclinics.uzh.ch

\author{
Evaluation of eating and \\ rumination behaviour \\ using a noseband pres- \\ sure sensor in cows after \\ right-flank laparotomy \\ for correction of left \\ displaced abomasum \\ U. Braun, L. Trösch,

